\title{
Yeni Kamu Hizmeti Düşüncesi: Değişen Kamu Hizmeti Anlayışı
}

\author{
Selçuk DENEK ${ }^{1}$
}

\section{Özet}

21. yüzyılın başlamasıyla birlikte bireylerin hayattan beklentileri değişmiştir. Bireyler devletten aldığı kamu hizmetlerinde de benzer şekilde bir değişim beklemektedir. Geleneksel yönetim anlayışıyla üretilen kamu hizmetleri verimsiz, kalitesiz ve yavaş bir şekilde sunulmaktadır. Yeni kamu yönetimi anlayışının popüler hale gelmesiyle birlikte sunulan hizmetlerin kalitesi ve hızında bir değişim olmuş ve özel sektördekine benzer bir şekilde sunulmaya başlamıştır. Bu durum sunulan hizmetlere olan memnuniyeti arttırmış olsa da hizmet sunulurken bireylerin vatandaş olarak değil müşteri olarak görülüp değerlendirilmesi bireylerde huzursuzluğa yol açmıştır. Karşısındaki otoritenin hizmeti sunarken devlet anlayışıyla değil de özel sektör anlayışıyla hareket etmesi ve bireylerin doğal hakkı olan kamu hizmetlerini bir müşteri gibi kullanır hale gelmesi kamu hizmetlerinin kamu yararı için mi yoksa kar için mi yapıldığı sorusunu akla getirmektedir. Bu durumun ortadan kaldırılması için ortaya çıkan yeni kamu hizmeti anlayışında devlet bireyleri hem vatandaş olarak görüp kamu yararı için hizmet etmeli hem de özel sektördeki gibi hızlı, kaliteli ve verimli bir şekilde kamu hizmetlerini sunmalı düşüncesi hakimdir. Çalışmamızda ilk olarak geleneksel yönetim anlayışının hizmet sunum şekli irdelenecek. Sonrasında ise özel sektör teknikleriyle hizmet sunma iddiasında olan yeni kamu yönetimi anlayışının hizmet sunum şekli değerlendirilecektir. Son olarak ise çalışmamızın esas konusu olan yeni kamu hizmet anlayışııın temellerinden bahsedilerek kamu hizmetinin bu anlayışa göre nasıl sunulması gerektiği fikri ortaya konulmaya çalışılacaktır.

Anahtar Kelimeler: Yeni kamu hizmeti, vatandaş odaklı hizmet, müşteri odaklı hizmet, kamu hizmeti.

\section{New Public Service Thought: Changing Public Sevice Concept}

\begin{abstract}
In the beginning of 21.century, expectation of individuals from life was changed. In the same way, individuals expect that delivery of public service must be changed. Public services which are produced by classical management thought are delivered slowly, unfavourably and inefficiently. On the other hand, when new pulbic management concept became popular, the quality and velocity of public services changed. Additionally, public services started to deliver as good as private sector. In this case, satisfaction of individuals are increased from public services but individuals feel anxious because they are considered as customers. There is a question about delivering public services: what is the purpose of public services? The purpose is profit or public welfare. The public services are a god-given right because the authority is government. Because of these reasons new public service thought aims to terminate this situation by considering individuals as citizens and by delivering the services as good as private sector services. Firstly, this study is going to analyze the delivering services of classical management. Next, this study is going to examine that how new public management delivers public services. Consequently, this study is trying to reval that what is the main discussion of new public service thought and how does the public service need to deliver according to this concept.
\end{abstract}

Key Words: New public service, citizen centered service, customer centered service, public service.

1 Arş. Gör., Aksaray Üniversitesi, Siyaset Bilimi ve Kamu Yönetimi Bölümü, selcuk.denk@gmail.com 


\section{Giriş}

21. yüzyılla birlikte insanların hayattan beklentileri, hayat standartları, toplumların ihtiyaçları büyük bir değişim geçirmiş ve geçirmektedir. Bu değişimlerle birlikte toplumun düzeninin temelini teşkil eden devlet örgütünün de yapısal değişikler yaşadığı ortadadır. Geleneksel yönetim anlayışıyla idare edile gelen devlet mekanizması zamanla hantal, verimsiz, israfçı, katı, hiyerarşik ve bürokratik yapısından kurtulmaya başlamıştır. Geleneksel yapının artık insanların ihtiyaçlarını karşılamakta yetersiz kaldığı kendini hissettirmiş ve özel sektör tekniklerini kullanan, daha verimlik, daha etkin, ekonomik, hızlı, kaliteli, profesyonel yönetim teknikleri kullanan yeni kamu yönetimi anlayışı ortaya çıkmıştır. Özel sektör işletmeleri gibi piyasa odaklı, profesyonel personellerle çalışan, performans odaklı, etkinliğin önemli olduğu, vatandaşın müşteriye dönüştügü bir yapı kamu hizmetlerinin yürütülmesinde kullanılır hale gelmiştir. Fakat vatandaşa müşteri gözüyle bakan, kullanan öder gibi kamu hizmetiyle bağdaşmayan ilkeleri ortaya çıkaran, kamu yararından ziyade piyasa odaklı işleyen bu sistem devleti, temel amacı devletin esas sahibi olan vatandaşa kamu hizmeti üretmek olan çizgisinden saptırmaya başlamıştır. Esas hedefinden sapan bu durum yeni kamu hizmeti anlayışıyla tekrardan rayına sokulmaya çalışılmaktadır. Yeni kamu hizmeti anlayışında devlet hizmeti müşteri için değil vatandaşı için üretir. Amacı piyasada özel sektörle yarışmak değil kamu yararı sağlamaktır. Demokrasiyi zirveye çıaran, vatandaşı temel paydaş olarak görüp yönetimde ve hizmet üretiminde onunla etkileşimde bulunmayı tavsiye eden, üretimden çok kamu yararını ön plana alan bir anlayışla kendini temellendiren yeni kamu hizmeti yaklaşımı bu çalışmada incelenecektir.

Çalışmanın ilk kısmında öncelikle konuya temel oluşturması açısından kavramsal çerçeve oluşturulacaktır. Bu kısımda kamu hizmeti kavramı açıklanacak, geleneksel ve yeni kamu yönetimi anlayışları genel olarak ifade edilecek, bu anlayışların kamu hizmeti üretim tarzı ortaya koyulacaktır. İkinci kısımda ise esas konumuz olan yeni kamu hizmeti anlayışı detaylı olarak ifade edilmeye çalışılacaktır. Yeni kamu hizmetinin ortaya çıkışı, temelleri, anlayışın ilkeleri, anlayışta önemli bir konumu bulunan yönetişim ve vatandaş odaklılık konuları detaylandırılacaktır. Son kısımda ise geleneksel ve yeni kamu yönetimi anlayışı ile yeni kamu hizmeti anlayışı temel ilkeler itibariyle karşılaştırılacaktır.

Çalışmamız literatür taraması kullanılarak oluşturulmuştur. Çalışmamızda açıklayıcı ve tanımlayıcı yöntem kullanılmakla birlikte karşılaştırma yöntemine de yer verilmiştir. Çalışmamız zaman, kaynak ve yazılış amacı kısıtlılıklarından dolayı hacim itibariyle çok kapsamlı değildir. Konumuzun literatürde henüz çok çalışılmamış olması da kaynak sıkıntısı teşkil etmektedir. Çalışmamızda kapsam sınırlılıkları itibariyle kamu hizmeti kavramının, geleneksel ve yeni kamu yönetimi anlayışlarının detaylarına girilmeyecektir. Çalışmamızda yeni kamu hizmeti anlayışı genel hatlarıyla ortaya koyulmaya çalışılacaktır. Çalışmamızın amacı kamu hizmeti kavramını, geleneksel ve yeni yönetim anlayışlarını ortaya koymak değildir. Çalışmamızın amacı kamu yönetimi yazınında henüz yeterli olarak değinilmemiş ve henüz genç bir çalışmalar ağı olan yeni kamu hizmeti anlayışının 
temellerini kısa ve öz bir şekilde ifade ederek literatürdeki boşluğu doldurmak ve bu alanda çalışma yapmak isteyecek araştırmacılara yeni bir kaynak ortaya koymaktır. Çalışmamızın temel argümanı geleneksel ve yeni kamu yönetimi anlayışlarının artık yetersiz kaldığını ve bu açığı kapatmak için yeni kamu hizmeti uygulamalarının gerekli olduğunu tartışmaktır.

\section{Kavramsal Çerçeve}

\subsection{Kamu Hizmeti Kavramı}

Kamu hizmeti "kamu kurumları tarafindan ya da bunların gözetimi altında özel girişime ait kurumlar tarafindan sağlanan hizmet" olarak ifade edilmektedir (Taş ve Aydın, 2010: 4). Sunulan bir hizmetin kamu hizmeti olarak nitelendirilebilmesi için ilgili hizmetin kamuya yöneltilmiş olması, kamuya faydalı olması ve kamuya sunulmuş sürekli ve muntazam faaliyetler olması gerekmektedir (Korkut vd., 2015: 112). Diğer taraftan kamu hizmeti devletin mevcudiyetinin sebebi olarak da gösterilmektedir (Sezer, 2008: 149). Kamu hizmeti idari eylemlerin etrafinda meydana gelmekte ve idarenin yerine getirmekle mesul olduğu faaliyetler olarak nitelendirilmektedir (Sezer, 2008: 149). Ayrıca Kavruk (2002: 15), devletin etkili ve çok kamu hizmeti sunduğunda güçlü devlet, kalitesiz ve az hizmet sunduğunda ise zayıf devlet olarak nitelenebileceğini ifade etmiştir.

Diğer taraftan kamu yönetiminin geçirdiği değişimden kamu hizmeti kavramının da etkilendiği ve hizmeti icra edenler tarafindan bir değişim yaşandığı ifade edilmektedir (Güngör, 2010: 24). Bu değişim üç dönem halinde ortaya koyulmuştur. İlk olarak 1929 buhranı öncesinde durumun liberal anlayış ekseninde şekillendiği ve kamu hizmetinin devletin esas faaliyet alanı olan diplomasi, güvenlik, savunma ve adalet hizmetleri ile sınırlandırıldığı kabul edilirken; 1929-1979 yılları arasındaki ikinci dönemde ise refah devleti anlayışının hakim olmasıyla birlikte devletin ekonomik alana müdahalesi artmış ve dolayısıyla idarenin faaliyetlerindeki genişleme kamu hizmetini de etkilerken çok sayıda bireysel ve toplumsal ihtiyacın karşılanması kamu hizmeti olarak nitelenmiştir; 1979 sonrası dönemde ise yeni liberal devlet anlayışı ortaya çıkınca kamu hizmeti kavramının içeriği tekrardan bir daralma geçirmiş ve devletin asli hizmetlerinin dışında kalan kısmı özel sektöre bırakarak sadece düzenleyici bir konumda kalması gerektiği kabul edilmiştir (Güngör, 2010: 24-25).

Tekrardan kavramın muhteviyatına dönmek gerekirse kamu hizmetlerinin sunumunda eşitlik prensibinin gözetilmesi gerekmektedir, bu hizmet kamu yararına yapılır, herhangi bir hizmetin kamu hizmeti olarak değerlendirilmesine siyasi irade karar verir ve genelde bu hizmet ücretsiz olarak sunulur (Taş ve Aydın, 2010: 5). Ayrıca kamunun sunduğu farklı hizmet türlerinden de bahsedilmektedir. Bunları Taş ve Aydın (2010: 5) şöyle sıralamıştır:

-Yönetsel kamu hizmetleri: Eğitim, sağlık gibi geleneksel kamu hizmetleridir.

-Ekonomik kamu hizmetleri: Endüstriyel ve ticari faaliyetler olarak hem kamu hizmeti hem de özel hizmet olarak nitelenebilirler.

-Sosyal kamu hizmetleri: Emeklilik ve sosyal güvenlik gibi hizmetler buraya dahil edilebilir.

-Bilimsel, teknik ve kültürel kamu hizmetleri: Bilim, teknik, tiyatro, müzik, sanat ve sinema gibi konularda sunulan faaliyetleri içine almaktadır. 
Ayrıca kamu hizmetlerinin süreklilik, değişkenlik ve uyum, eşitlik, tarafsızlık (Taş ve Aydın: 2010: 5), bedelsizlik ve yargı denetimi (Müftüoğlu, 2011: 78-79) gibi ilkeleri bulunmaktadır.

\subsection{Kamusallık ve Kamusal Alan Tartışması}

Jürgen Habermas "Kamusallığın Yapısal Dönüşümü” isimli kitabı ile 1962 yılında kamusal alan ve özel alan tartışmalarını hararetlendirmiştir (Yükselbaba, 2008: 227). Habermas'ın konuyu gündeme taşımasının ardından kamusal alan tartışmaları farklı görüşler etrafında çeşitlenmeye başlamıştır (Yükselbaba, 2008: 227). Kamusal alan tanımları da bu doğrultuda tanımı yapan kişilerin bakış açılarına ve dünya görüşlerine göre şekillenmektedir (Yükselbaba, 2008: 227). Bu açıdan kamusal alan kavramı "kamu otoritesinin geçerli olduğu yer, çoğulculuğun, renkliliğin ve özgürlüğün olduğu alan, kamu görevlisinin bulunduğu yer" şeklinde farklı şekilde ifade edilmektedir (Yükselbaba, 2008: 227). Habermas'ın kamusal alanı herkese açık ve hiç bir çıkar içermeyen bir yapıya sahiptir (Hasdemir ve Coşkun, 2008: 127). Ayrıca Habermas'da kamusal alan, devlet otoritesinin emir ve baskılarından, sermayenin kontrolünden ve kar amacından da bağımsızdır (Hasdemir ve Coşkun: 2008: 127). Diğer taraftan liberal dönem devlet-toplum ayrımı konusuna da değinen Habermas, refah devleti anlayışı ile devletin özel alana müdahalesinin neticesinde bu ayrımında mevcudiyetini yitirdiğini ve kamusal alanın dönüşüm geçirdiğini savunmaktadır (Hasdemir ve Coşkun, 2008: 128). Devletin topluma müdahalesinin artmasıyla birlikte özel sektörün de idare üzerinde etkisinin arttığını ve bürokrasinin de özel çıkarlardan etkilenmesi sonucunda devlet-toplum arasındaki ayrımın belirginliğini yitirdiği Habermas tarafından dile getirilmektedir (Hasdemir ve Coşkun, 2008: 128). Habermas üç çeşit kamusal alandan bahsetmektedir (Karadağ: 2003: 185). Bunları, "temsili kamu, edebi kamu ve siyasal kamu" olarak sıralamıştır (Karadağ: 2003: 185). Habermas kamusal alan anlayışını ortaya koyarken "sonuçlarından doğrudan veya dolaylı olarak etkilenebilecek olan herkesin kamusal söyleme katılması gerektiğı̆” görüşünü savunmaktadır (Karadağ, 2003: 187). Bir alanın kamusal alan olarak nitelendirilebilmesi için bir otoriteden bağımsız, demokratik, birey hak ve özgürlüklerini gözeten bir yapıda olması gerekmektedir (Yegen, 2013: 134).

Habermas'ın kamusal alan düşüncesi çeşitli görüşler tarafından, günümüzdeki kapitalizm şartlarında mevcut olan liberal demokrasi eleştirisi ve sosyalist demokratik yaşam tarzının oluşturulmasında göz ardı edilemez bir düşünce olarak değerlendirilmektedir (Özbek, 2004: 24). Habermas'ın anlayışını dikkate değer kılan kamusal alan düşüncesini “eleştirel akıl ve rasyonel rızaya dayalı modern özyönetim ilkesiyle tarihsel bağını yeniden kurmasından, hukuk devleti ve demokrasi arasındaki ilişkiyi radikalleştirmesinden ve kamusallık ilkesinin bugünün koşulları açısından gerçekleşebilirliğini irdelerken, analizini kapitalizmin tarihsel ve bütünleyici mantı̆̆ içinde, çok yönlü bir şekilde kavramlaştırmasından" kaynaklandığı ifade edilmektedir (Özbek, 2004: 24). Habermas kendi anlayışını "radikal demokrasi" ve "modernlik projesinin demokrasi açısından yeniden kurulması" şeklinde isimlendirmektedir (Özbek, 2004: 24). Habermas'ın kamusal alan anlayış1 kamusal alanın genişletilmesiyle kendini gösteren biçimsel demokrasinin ortaya çıkışını tam olarak sahip olduğu konuma oturtmayı da sağlamıştır (Özbek, 2004: 26). Habermas'a göre kamusal alan sivil 
toplumun içinden meydana gelen kendine has bir alandır (Özbek, 2004: 27). Kamusal alan kavramı devletten ayrı ve devlete karşı fikirlerin ortaya çıktı̆̆ bir alan olarak tanımlanmaktadır (Özbek, 2004: 28). Habermas kamusal alan kavramını açıklarken "toplumsal yaşamımız içinde, kamuoyuna benzer bir şeyin oluşturulabildiği bir alanı" ifade etmekte ve bu alana tüm vatandaşların erişiminin garanti edildiğini savunmaktadır (Habermas, 2004: 95). Bireylerin kamusal bir bütün oluşturarak bir araya geldikleri her fikir alışverişinde bir kamusal alan ortaya çıkmış olur (Habermas, 2004: 95). Devlet otoritesi kamusal alanın kontrol ediyor denilmesine rağmen Habermas devletin esasen kamusal alanın bir parçası olmadığını savunur (Habermas, 2004: 95). Habermasa göre "sosyal refah devleti içinde hala saklanan kamusal alan fikri, yani özel bireyler arasındaki kamusal tartışma ortamı aracılığıyla iktidarın rasyonelleştirilmesi fikri, kamusal alanın yapısal dönüşümü içinde ortadan kalkma tehlikesiyle karşı karşıyadır" (Habermas, 2004: 102).

\subsection{Geleneksel Kamu Yönetimi Anlayışı}

Geleneksel kamu yönetimi ve yönetim bilimi yaklaşımları denilince akla ilk gelen Weber, Taylor, Fayol, Wilson gibi isimlerdir. Bu isimler çalışmalarıyla ve yaklaşımlarıyla geleneksel yönetim anlayışını ortaya çıkarmışlardır. Weber'in "İdeal Bürokrasisi”, Taylor'ın "Bilimsel Yönetimin İlkeleri”, Wilson'un "Yönetimin İncelenmesi” çalışması, Fayol'un "Genel ve Endüstriyel Yönetim” isimli çalışmaları kamu yönetimi ve yönetim bilimi literatüründe geleneksel yönetim anlayışının oluşmasını sağlayan çalışmalar olarak ifade edilir.

Geleneksel yönetim anlayışının temellerini Eryılmaz (2010: 16-17) şu dört ilke etrafinda toplamıştır:

-Geleneksel kamu yönetimi büyük oranda Weber'in bürokrasi modeline göre örgütlenmiştir. $\mathrm{Bu}$ model ayrıntılı kurallara, biçimselliğe, gayri şahsiliğe, katı hiyerarşik yapılanmalara dayanan kariyeri esas alan merkeziyetçi bir özellik benimsemektedir. Bunların kamu yönetiminde verimliliği, etkinliği ve tarafsızlığı sağlayacağı düşünülmüştü.

-Devlet kamusal mal ve hizmetlerin üretilmesinde ve dağıtılmasında kendi bürokrasisini kullanarak doğrudan vazife yapmalıdır. Mal ve hizmet üretilmesinde standart prosedürler ortaya konuldu. Kamu çalışanlarının hareketleri ayrıntılı kurallara bağlandı. Böylece topluma hizmet etmek yerine amaçlar dikkate alınmadan kuralları katı bir şekilde uygulamak temel metot haline geldi.

-Siyasi ve idari konular birbirinden ayrılmalıdır ve idarenin görevi kuralları ve emirleri uygulamakla sınırlıdır. Kamu kurumlarının denetimi merkeziyetçi yöntemle, hiyerarşik basamaklar vesilesiyle ayrıntılı olarak yapılmalıdır. Denetimde temel olan yasal ilkelere uygun hareket edilip edilmediğinin kontrolünden ibaret olup kurumların misyonları, hedefleri ve maliyetleri ikinci planda kalmaktadir.

-Kamu yönetimi özel yönetimden farklıdır. Kamu yönetimi profesyonel bir bürokrasi ve çalışanların hayat boyu istihdamına göre düzenlenmektedir. Bu mekanizma tüm iktidarlara karşı eşit mesafede ve tarafsız bir şekilde durmalı ve faaliyet göstermelidir denilmiştir. Ayrıca topluma ya da 
piyasaya karşı bir duyarlılığı olmayan sadece politikacıların ve bürokratların talimatlarına göre faaliyet göstermektedir.

\subsubsection{Geleneksel Kamu Yönetimi Anlayışının Kamu Hizmeti Yaklaşımı}

Geleneksel anlayışa göre devlet kamu hizmetlerinin üretiminde ve dağıtımında kendi örgütünü kullanarak doğrudan görev almak durumundadır (Korkut vd., 2015: 109). Genelde kamu örgütlerine özgü eski bürokratik yaklaşım ve politika üretim süreçleriyle birlikte kamusal hizmet üretimi verimli ve etkin olarak üretilmemektedir (Özcan ve Ağca, 2010: 2). Taylor'ın makine metaforuna göre çalışmasını sürdüren klasik yönetim anlayışı kamu hizmetlerinin üretim ve dağıtım sürecini de doğal olarak bu şekilde gerçekleştirmekte ve bu durum bürokratik yapıların hantal, katı ve hiyerarşik durumlarının kamu hizmeti üretimine de yansımasına neden olmaktadır. Denhardt ve Denhardt (2000: 551-552) geleneksel yönetim anlayışının kamu hizmeti üretiminde şu şekilde davrandığını işaret etmektedir:

-Devletin vazifesi kamu hizmetlerini sunmak ve dağıtmaktır ve bu faaliyeti gerçekleştirirken en uygun yapı merkezi bürokrasidir.

-Devlet hizmet sunumunda siyasal olarak tarafsızdır ve kamu çalışanları sadece kamunun amaçlarını yerine getirmekle vazifelidir.

-Faaliyetler yerine getirilirken hiyerarşik yapılanma kullanılmaktadır ve bundan dolayı uygulanan faaliyetlerin dişına çıkmak çok zordur.

-Vatandaşların yapılan işlere katılımı neredeyse yoktur çünkü bürokratik mekanizma dış müdahalelere kapalı bir örgüt yapısından oluşmaktadır.

Özetlemek gerekirse, geleneksel anlayış hantal ve katı yapısından dolayı hizmet üretiminde ve sunumunda yetersiz kalmaktadır. Bu nedenle kamu hizmetleri bürokratik engellerle dolu klasik yap1 içerisinde sıkışıp kalmakta ve hizmetlerin sunumu ve üretimi hem etkin hem de verimli bir şekilde sağlanamamaktadır.

\subsection{Yeni Kamu Yönetimi Anlayışı}

Yeni kamu yönetimi anlayışının iki farklı akımın birleşiminden ortaya çıtığı ve bunlardan bir tanesini kamu tercihi teorisi, asil-vekil teorisi ve politikayı bir piyasa fenomeni olarak kabul eden işlem maliyeti teorisi üzerine kurulan yeni kamusal ekonomi meydana getirirken; diğerini ise işletmecilik yaklaşımı meydana getirmektedir (Uysal, 2013: 17-18). Yeni genel bir ifadeyle yeni kamu yönetimi anlayışı kamu tercihi ve işletmecilik teorileri tarafından şekillendirilmiştir (Çakır, 2014: 77). Kamu tercihi teorisi için ise Ökmen ve Demir (2010: 33) şunları ifade etmiştir: "Özünde devletin büyümesine ve hükümetin "hamiyetperver" olduğu ve kamu yarart ve ortak iyi ile ilgilendiği "mit"ine karşı bir tepki olarak ortaya çıkmıştır. Tüm bireylerin kendi çıkarını düşünen ve faydalarını maksimize etmek isteyen kişiler oldukları varsayımından hareket eden kamu tercihi teorisyenleri, hükümetlerin hamiyetperver olmadıklarını, kendi çıkarlarını düşündüklerini, ve genellikle de kötücül olduklarını göstermeye çalışmışlardır." Bu anlayış aslında bürokratların kamu yararının savunucuları olmadığını ve sadece kendi çıkarlarını düşündüklerini ifade etmektedir (Ökmen ve Demir, 2010: 33). Downs ise 
bürokratların kendi çıkarlarını düşündüklerini fakat vatandaşa iyi bir biçimde hizmet sunmanın da onların motivasyon kaynaklarından biri olabileceğini ifade etmiştir (Ökmen ve Demir, 2010: 33-34). Ayrıca Güler (2005: 4)'e göre “Kamu politikası alanındaki çalışmalar, politika değerlendirme araştırmaların kamu tercihi kuramına, maliyet-fayda analizlerine, rasyonel tercih modellerine, kısaca iktisat alanından alınan açıklamalara dayandırmışlardır. Daha sonra, politika uygulama aşamasına dönük çalışmaların öne çıktı̆̆ bu aşamanın analizlerinde dikkatin "public management" kavramına odaklandiğı görülmektedir. Bu terimin (management) kullanılmasıyla, sevk-idare davranışının ekonomik yorumu kastedilmektedir". Dolayısıyla yeni kamu yönetimi anlayışının bu tarz yaklaşımların üzerine inşa edildiği ortaya koyulabilir.

Diğer taraftan kamu yönetiminde klasik anlayışın başarısızlıkları yeni model arayışlarına girilmesini zaruri hale getirmiştir. Özellikle 1980’lerden sonra kamu yönetimi tüm dünyada değişim geçirmeye başlamıştır. Bu değişimlerde "katı, hiyerarşik ve bürokratik kamu yönetimi, esnek, piyasa tabanlı kamu yönetimine dönüştürülmüştür" (Özer, 2005: 4). Bu durumu basit bir değişimden ziyade klasik yönetim anlayışının temel ilkelerine karşı bir meydan okuma olarak gören bir paradigma değişimi olarak nitelendirmek daha mantıklı görünmektedir (Özer, 2005: 4). Kamu idarelerinin özel sektöre göre daha dar ve sınırlı işlevlere sahip olduğu düşünüldüğünde "kamu işletme yönetimine dönüs, teori ve fonksiyon olarak oldukça temel ve kapsaml bir değişim anlamına gelmektedir" (Özer, 2005: 4). Bu yeni yaklaşım örgütsel karar vermede rasyonel anlayışı ortaya koyarken özel sektörle de alakalı olarak değerlendirilmektedir (Özer, 2005: 5). Yeni kamu yönetimi yaklaşımı özel sektör yönetim metotlarından etkilenmekte, büyük ve karmaşık örgütlerin nasıl yönetileceği konusunda da yaklaşımlar ortaya koymaktadır (Özer, 2005: 6). Ayrıca özel sektörün ve klasik kamu yönetimi anlayışının arasında çok özel bir konumda durmaktadır (Özer, 2005: 6). Diğer taraftan bu anlayış rekabete, kullanıcı tercihlerine, açıklığa, şeffaflığa, motivasyona, profesyonel yönetime, teknik uzmanlığa, yetki devrine ve performansa da vurgu yapmaktadır (Özer, 2005: 8). Dahası bu yaklaşımla birlikte hiyerarşik katı yapılardan ziyade piyasalara öncelik vermek, müşteriye karşı sorumluluk, süreçlerden çok sonuçlara odaklanmak, kaçınmaktan ziyade sorumluluk almak, kamu yönetiminden çok işletme yönetimine yoğunlaşmak, ekonomiklik, etkinlik, verimlilik, yönetimsel bilgi ve beceriler kamu sektörü için öncelik haline gelmiştir (Özer, 2005: 7).

Yeni kamu yönetiminin ilkelerinden bir kısmının ise şu şekilde olduğu literatürde ifade edilmiştir (Arslan, 2010: 27):

-Açıklık,

-Performans değerleme, sayısal olarak ölçülebilen ve daha çok çıktılara yönelik ölçüm standartlarına dayal1,

-Merkeziyetçi bürokrasinin etkisinden kurtularak yerelleşmeye daha fazla önem veren,

-Rekabet ortamı oluşturarak ve bu sayede maliyetleri azaltmak,

-İstihdam, planlama gibi alanlarda özel sektör uygulamalarını örnek almak (belli süreyle çalışma, stratejik plan yapma, ürün başına maaş alma vs.) 
-Tasarruf ve verimliliğe daha fazla önem verme.

Yeni kamu yönetimi anlayışıyla birlikte yöneticilerin daha rahat hareket etme imkanına sahip olması gerektiği düşünülmüş ve profesyonel yönetim yeteneklerine sahip olması gerektiği ifade edilmiştir (Arslan, 2010: 27).

Özetle yeni kamu yönetimi anlayışı daha etkin ve verimli bir yaklaşım geliştirmekle beraber klasik yapının katı ve mekanik anlayışını kırmayı hedeflemektedir.

\subsubsection{Yeni Kamu Yönetimi Anlayışının Kamu Hizmeti Yaklaşımı}

Yeni kamu yönetimi yaklaşımı kamu hizmetlerinin sunumunda etkinlik, verimlilik, ekonomiklik, kalite gibi kavramlara dikkat etmektedir (Arslan, 2010: 34). Bu yaklaşımla kamu hizmetlerinin sunumuna uygun yeni örgütlenmeler benimsenmektedir (Arslan, 2010: 22). Klasik bürokratik yapılanmaların merkeziyetçi, katı, karmaşık kuralları ve hantal yapısı artık kamu hizmetlerinin sunumunda beklentileri karşılayamamaktadır (Arslan, 2010: 23). Klasik yapı hem kaynakları israf etmekte hem de hizmetleri pahalı sunmaktadır fakat yeni anlayışla bu durumun değiştirilmesi ön görülmüştür (Arslan, 2010: 23). Dahası yeni anlayış ilgili reformlar ve özelleştirmelerle kamu hizmeti anlayışını da değiştirmek istemiştir (Arslan, 2010: 26). Devletin düzenleme alanını daraltarak deregülasyonlarla birlikte hizmet sunumu çeşitlendirilmeye çalışılmakta ve devletin özel sektör üzerindeki denetimi hafifletilmektedir (Arslan, 2010: 26). Ayrıca, adem-i merkeziyetçi örgütlenme, performans ölçüm kriterleri yapma ve ilgili hizmetten faydalananları karar mekanizmalarına dahil eden (Arslan, 2010: 26) bu yaklaşım hizmet sunumunda kaliteyi arttırmayı amaçlamaktadır. Diğer taraftan kamu hizmetlerinin sunumunda mahalli idareleri de ön plana koyarak yerelleşme ve hizmette halka yakınlık ilkeleri etkin kılınmak istenmektedir (Arslan, 2010: 28). Kamu hizmetlerinin kalitesi ve hizmetten faydalanan vatandaşın tatmini meseleleri de ön plana çıkmaktadır (Arslan, 2010: 29). Mal ve hizmetlerin üretiminde ise piyasanın öncelikli olması gerektiği tartış1lırken ilgili hizmetlerin piyasa kurallarına uygun olarak sunulması amaçlanmaktadır (Arslan, 2010: 29). 21. Yüzyılın gelişmeleriyle birlikte hız, değişim, dönüşüm, tüketim, rekabet, reklam, iletişim ve teknoloji gibi unsurlar hizmetlerin sunumunda yeni kamu yönetimi anlayışının benimsediği ilkelerdir denilebilir (Arslan, 2010: 31). Yeni anlayışla birlikte vatandaş yerine müşteri kavramı kullanılmaya başlanmış, esnek üretim modelleri benimsenmiş, hizmetlerin bedelsiz sunumu yerine kullanan öder anlayışı ön plana çıkmaya başlamıştır (Arslan, 2010: 33). Örneğin, bir şehirden diğerine gitmek için eski bozuk ve daha uzun olan karayolunu kullanmak ücretsizken, yeni, sağlam ve daha kısa olan ve daha hızlı gidilebilen bir otoyolu kullanmak ücretlidir.

Özetle, yeni kamu yönetimi anlayışıla birlikte klasik anlayışın verimsiz yapısı terkedilirken, daha hızlı, kaliteli ve hizmet alanların ihtiyaçlarına daha iyi cevap veren yapılar benimsenmiş ve kamu hizmetlerinin sunumu bu anlayışlar çerçevesinde yapılmaya çalışılmıştır. 


\section{Yeni Kamu Hizmeti Anlayışı}

Yeni kamu hizmeti yaklaşımı klasik yönetim anlayışının eksikleri ve eleştirilerini ve yeni kamu yönetimi anlayışının ise eksiklerini gidermeye yönelik üçüncü bir yol olarak sunulmaktadır (Özcan ve Ağca, 2010: 16). Bu yaklaşımda vatandaşın devletin sahibi olduğu konusuna vurgu yapılarak kamudaki idarecilerin görevinin vatandaşlara hizmet etmek ve onları güçlendirmek olduğu ifade edilmektedir (Özcan ve Ağca, 2010: 16). Özcan ve Ağca (2010: 16)'nın ifadesine göre “ortodoks kamu yönetiminin "dizayn etmek ve uygulamak”, yeni kamu işletmeciliğinin "yönetmek” olarak özetlediği hakim yönelimin, "hizmet etmek” amacına dönüşü̈̆̈̈ bu yeni perspektifin dayandiğı en önemli unsurlardan biri demokratik vatandaşlıktır (diğer üçü de, sivil toplum, örgütsel hümanizm ve söylem kuramıdır)". Ayrıca, "devletin varlık nedeninin, vatandaşların bireysel çıkarlarına uygun seçim yapma prosedürlerini (oy kullanmak gibi) garanti etmek olarak algılandiğı yeni kamu işletmeciliğine karşın, bu yeni hareket vatandaşın bireysel çıkardan öte kamu çıkarıyla ilgilenebileceği, devlet işleriyle ilgili olarak bilgilenebileceği, kamuya aidiyet hissedeceği, sorumluluk alacağı, kısaca aktif katılımcı olabileceği bir anlayışı getirir" (Özcan ve Ağca, 2010: 16). Bu yeni anlayışa göre vatandaş tüketici, müşteri veya seçmen olarak değerlendirilmek yerine sadece vatandaş olarak değerlendirilmeli ve vatandaş kamu hizmetlerinin müşterisi olarak değil üreticisi ve alıcısı olarak değerlendirilmelidir (Özcan ve Ağca, 2010: 16).

Yeni kamu hizmeti anlayışının şu yedi temel ilkeyi benimsediği literatürde ifade edilmektedir (Özcan ve Ağca, 2010: 16-17):

-Yönetmek yerine hizmet etmek gereklidir,

-Kamunun çıkarı yan ürün olarak değil asıl ürün olarak değerlendirilmelidir,

-Stratejik düşünmek ve demokratik hareket etmek önemlidir,

-Hizmet müşteriye değil vatandaşa sunulur,

-Sorumluluk önemli bir konudur,

-Verimlilikten ziyade insana değer vermek daha önemlidir,

-Girişimciliğe değil vatandaşa ve kamu hizmetine önem verilmelidir.

Kısacası yeni kamu hizmeti yaklaşımı kamu yönetiminde demokratik değerleri, vatandaşlı̆̆ ve kamu yararını merkeze alan kamu hizmetini desteklemektedir (Ersöz, 2010: 5). Genel olarak yeni kamu hizmeti anlayışını bu şekilde özetlemek mümkündür. Alt başlıklarda konunun detayına değinilecektir.

\subsection{Yeni Kamu Hizmeti Anlayışının Ortaya Çıkışı ve Temelleri}

İkinci Dünya Savaşından sonraki dönemde kamu hizmetlerinde tüm vatandaşlara uygun olabilecek tarzda tek tip olarak hizmet sunan bir yöntem kullanılmaktaydı ve bu hizmetler güçlü merkezi idarelerce sunulmaktaydı (Uysal, 2013: 24). Küreselleşmeyle birlikte kamu hizmetlerine olan talepler değişmeye başlamış ve mevcut kamu hizmeti anlayışı da değişime girmiştir (Uysal, 2013: 24). Devletlerin her vatandaşa eşit yaklaşma anlayışıyla beraber bireylerin çeşitli ve değişik ihtiyaçları dikkatten kaçmıştır (Uysal, 2013: 24). Son dönemde ise vatandaşların iyileşen yaşam standartları, 
farklı toplumlar ve bireyler için kamu hizmetlerine dönük seçim yapma, cevap verebilirlik, erişebilirlik ve esneklik beklentilerini yükseltmiştir (Uysal, 2013: 24). Ayrıca karmaşık düzenlemeler ve formlar, bilgi eksikliği, performans standartlarının yokluğu, hesap verilebilirliğin olmayışı, yolsuzluk ve güven eksikliği gibi meseleler de kamu hizmetlerinden faydalananlarda yani vatandaşlarda hizmetlerden memnun olma durumunu azaltmıştır (Uysal, 2013: 24). Tüm bunlarla birlikte kamu hizmetlerinin içeriği, türleri ve sunumunda farklılaşmanın gerekli olduğu anlaşılmış ve sivil toplum kültürünün de kuvvetlenmesiyle birlikte kamu hizmetlerinin yeni bir forma kavuşturulması zaruri bir hal almıştır (Uysal, 2013: 24).

Yeni kamu hizmeti yaklaşımı klasik kamu yönetimi ve yeni kamu yönetimi anlayışlarının üzerinde konumlanmakla beraber bunların eleştirileri ve eksiklikleri üstüne inşa edilmiştir. Klasik yönetim anlayışının hantal, katı, kalitesiz bir şekilde hizmetleri sunması ve vatandaşın isteklerine günün şartlarına uygun cevaplar verememesi sonucunda hizmet sunumunda yetersiz olduğu yıllardır uygulana gelen durumdan anlaşılmaktadır. Yeni kamu yönetimi ise vatandaşa daha çok müşteri olarak yaklaşması, özel sektör mantığıyla işlerini yürütmesi ve kullanan öder gibi anlayışlarla hareket etmesi sebebiyle eleştirilere maruz kalmaktadır. Yeni kamu hizmeti yaklaşımı bu eleştirileri kullanarak iki anlayışın çok üzerinde bir konumlanmayla ortaya çıkmıştır.

Yeni kamu hizmeti yaklaşımını ortaya çıkaran Denhardt'lar (Janet V. Denhardt ve Robert B. Denhardt) demokratik vatandaşl1k, topluluk ve sivil toplum modelinin benimsenmesi ve örgütsel hümanizm anlayışlarının yeni kamu hizmeti içerisinde bulunduğunu ifade etmişlerdir (Denhardt ve Denhardt, 2000: 550).

Eleştirel okulun temsilcilerinden sayılan Denhardt'lar modern kamu yönetiminin eleştirisini Frankfurt Okulu ve Habermas'ın fikirlerinden etkilenerek ortaya çıkartmışlardır (Kantarcıoğlu, 2016: 43). Denhart'lar eski ve yeni olarak ikiye ayırdıkları kamu yönetimi disiplininin genel bir ifadeyle işletme bilimine yakın konumlandığını, özgünlük ortaya koyma bakımından yetersiz kaldığını, verimlilik, etkinlik, rasyonellik ve karlılık gibi konuların temel alınmasının siyaset ve vatandaşlık gibi unsurlardan uzaklaşılmasına neden olduğunu ve teknik problemler üzerine odaklanıldığını ifade etmektedirler (Kantarcıoğlu, 2016: 43-44). Yeni kamu hizmeti anlayışı bu eleştiriler çerçevesinde şekillenmiştir (Kantarcıoğlu, 2016: 44). Bu yaklaşım "kamu hizmetini, demokratik yönetişimi ve sivil katılımı merkezine yerleştiren, yönetişim sistemi içinde kamu yöneticilerinin rolleri hakkındaki bir dizi düşünceyi barındıran hareket olarak" ifade edilmektedir (Kantarcığlu, 2016: 44). Vatandaşları müşteri olarak görmeyen bu yaklaşıma göre vatandaş bir müşteriden ziyaden devletin sahibi olarak konumlandırılmaktadır (Kantarcığlu, 2016: 45). Yeni kamu hizmeti yaklaşımının dört teoriye dayandırıldığı, eski ve yeni kamu yönetimi anlayışından farklılaştığı ifade edilmekle beraber bu dört teorinin "demokratik yurttaşlık teorileri, toplum ve sivil toplum modelleri, örgütsel hümanizm ve yeni kamu yönetimi ve post-modern kamu yönetimi" olduğu Denhardt'lar tarafindan ifade edilmiştir (Kantarcıoğulu, 2016: 45). Denhart'lar bu yaklaşımı vatandaşlık kavramı üzerine inşa etmekle birlikte vatandaşlık kavramını ikiye ayırmışlardır (Kantarcıoğlu, 2016: 45). Bunlardan ilki, hukuk sistemi 
içerisinde hakları ve sorumlulukları olan vatandaş ikincisi ise, vatandaşların hukuki statülerden bağımsız bir şekilde siyasi bir topluluğun üyesi olması ve vatandaşların siyasi sisteme etki etme kapasiteleriyle alakalı olan aktif vatandaşlık kavramını dile getirmekle birlikte Denhardt'lar bu ikinci yaklaşımı temel almaktadırlar (Kantarcıoğlu, 2016: 45). Bunlarla birlikte yeni kamu hizmeti yaklaşımının üzerinde konumlandığı vatandaşlığın “aktif bir katılımı, genel çıkarı, kamu yararını, kamusal işlere katılımı, kişinin kendi çıkarlarını bir kenara bırakıp toplumun ortak çıkarını gözetmesini, devlet işlerine ilgi duymayl, demokrasiyi, bireysel hakları korumayı" yani yüksek vatandaşlı̆̆ dile getirdiği belirtilmektedir (Kantarcıoğlu, 2016: 46).

Yeni kamu hizmeti anlayışı idarenin yükümlülüklerini demokratik ve sosyal ilkeler üzerine konumlandırmaktadır ve kamu yararının tek üstün değer olduğunu da ortaya koymaktadır (Genç, 2010: 149). Diğer taraftan yeni kamu hizmeti yaklaşımı hesap verebilirlik kavramını da bünyesinde barındırmaktadır (Genç, 2010: 149). Bu kavramla birlikte kamu çalışanlarının yalnız siyasi ve kanuni sorumluluklarının olmadığı aynı zamanda topluma, siyasi kurallara, profesyonellik kriterlerine, vatandaşların talep ve çıkarlarına karşı da duyarlı olması gerektiği ve yeni kamu hizmetinin demokratik ideallerin ve hakların temelinden beslendiği ifade edilmektedir (Genç, 2010: 149). Yeni kamu hizmeti güçlü bir demokrasiye sahip olmak için devletin kendisini toplumun kalbine yerleştirmesi, vatandaşla işbirliği yaparak sosyal problemlerin üstesinden gelmesi, hizmetleri geliştirmesi ve toplumun ihtiyaçlarıyla ve değerleriyle uyumlu olması gerektiğini belirtmektedir (Genç, 2010: 149). Yeni kamu hizmeti yaklaşımına "kamu yönetiminde eşitlik ve etkinliğin yanında sosyal adaleti öneren, pozitivizmi reddeden, kapitalizm-demokrasi çatışması üzerinde duran, kamu yönetiminin teori kadar güncel sorunlarla da ilgilenmesi gerektiğini savunan, siyaset-yönetim ayrımına karşı çıkan, katılım ve temsilin önemine vurgu yapan, D.Waldo, G.Fredericson, M.Harmon, J. Raws'un fikirleriyle öncülüğ̈̈nü yaptı̆̆ Yeni Kamu Yönetimi Hareketi, Waldo'nun çalışmaları, Sheldon Wolin'in çalışmaları, demokratik vatandaşlık teorisi, topluluk ve sivil toplum modelleri, örgütsel hümanizm ve söylem teorisi” gibi anlayışların temel oluşturduğu Denhardt'lar tarafindan dile getirilmiştir (Genç, 2010: 150). Ayrıca post-modernizm de yeni kamu hizmetine etki eden anlayışlardandır. $\mathrm{Bu}$ anlayışa göre kamu yönetimi tüm siyasi gruplarla, vatandaşlarla ve yönetici konumunda olanlarla açık bir diyalog içerisinde bulunmalıdır (Genç, 2010: 152). Post-modernizmin hakim olduğu toplumda kamu yönetiminin demokratik, insan haklarına saygılı, temel fonksiyonları icra ederken meşru davranan, aşırı merkeziyetçilikten uzak ve mümkün mertebe yerelleşmiş olduğu ifade edilmektedir (Genç, 2010: 152).

Sonuç olarak yeni kamu hizmeti yaklaşımı "demokratik yurttaşlık kuramları, topluluk (yerellik) ve sivil toplum modelleri, örgütsel insanilik ve yeni kamu yönetimi, postmodern kamu yönetimi” olarak say1labilecek dört farklı kanaldan beslenerek oluşmuştur (Güler, 2005: 4-5).

Özetlemek gerekirse, yeni kamu hizmeti yaklaşımının hizmet sunumu, yönetişim mekanizmasını kullanarak vatandaşların yönetime katıldığı, siyasilerle, kamu idarecileriyle, sivil 
toplum örgütleri ve topluluklarıyla beraber hizmet sunumunun belirlenmesi anlayışını ifade etmektedir (Atmaca, 2012: 95).

\subsection{Yeni Kamu Hizmeti Anlayışının İlkeleri ve Özellikleri}

Denhardt'lar yeni kamu hizmetinin ilkelerini şu şekilde sıralamışlardır (Uysal, 2013: 25-27, Aydın, 2013: 22, Atmaca, 2012: 97, Ersöz, 2010: 33-34, Sezer, 2008: 153-154, Genç, 2010: 153-158):

-Dümen tutan olmaktan ziyade hizmet eden olmak: Yeni kamu hizmeti yaklaşımında bir kamu çalışanı, vatandaşı sıkı bir şekilde kontrol etmek ve yönlendirmek yerine onlara yardımcı olup, onların ihtiyaçlarını bir araya toplamalı, ortak çıkarların paylaşılmasını ve korunmasını sağlamalıdır. Günümüzde birçok kamu politikası çeşitli gruplarla etkileşim içinde bulunarak kararlaştırılmakta ve ortaya çıkan sorunlar da çözülmeye çalışılmaktadır. Yeni kamu hizmetinde kamu görevlileri artık vatandaşın talepleri karşısında sadece evet veya hayır demek yerine beraber çalışarak nasıl yapılması gerektiğini araştırır. Bu yeni rol kamu görevlisine sadece yönetsel kontrol değil, müzakere, çatışma çözümü, arabuluculuk gibi yeni bazı sorumluluklar da getirmektedir.

-Üretim yapmak değil kamusal çıkar amaçtır: Kamu yöneticileri, toplumu kapsayan ve toplumca paylaşılan bir unsur olan kamusal yararın oluşturulması ve gelişmesine katkıda bulunmalıdır. Amaç, bireysel tercihler tarafından yönlendirilen hızlı çözümlerin bulunmasından ziyade, ortak çıkarların oluşturulması ve sorumlulukların paylaşılmasıdır. Böylece, devlet kamusal sorunlara çözüm bulmalı fakat bu çözümler kamu yararıyla uyumsuz olmamalıdır. Kamusal çıkarın oluşturulması sürecine siyasiler, yöneticiler ve vatandaşlar dahil edilmelidir. Özetle, kamu çalışanları vatandaşların düşüncelerini paylaşabilecekleri, birbirlerinin taleplerini anlayabilecekleri ve daha geniş bir ölçekte kamu yararı düşüncesini geliştirebilecekleri bir saha ortaya koymalıdırlar.

-Stratejik düşünmek ve demokratik davranmak: Kamu politikalarının yapılmasında, ne geleneksel kamu yönetiminde olduğu gibi hiyerarşik bir anlayış ne de yeni kamu yönetimi anlayışındaki özel sektör ve faydacı yaklaşım benimsenmelidir. Kamusal ihtiyaçların giderilmesine yönelik politika ve programlar, vatandaşlar sürece dahil edilerek, işbirliği ve yönetişim anlayışı içinde daha etkin ve güvenli bir şekilde inşa edilip sunulabilir. Böylece, vatandaşların ihtiyaçları da daha demokratik ve sorumlu bir şekilde giderilmiş olur. Bunun için vatandaşı yetkilendiren, cesaretlendiren ve ona sorumluluk veren bir liderlik anlayışına gerek vardır.

-Hizmet müşteriler için değil vatandaşlar içindir: Kamu çıkarı, kişisel çıkarların toplamından ziyade paylaşılan değerlere ilişkin etkileşimden ortaya çıkar. Bu nedenle, kamu çalışanları sadece vatandaşların taleplerine cevap vermekle kalmaz; bununla birlikte vatandaşlarla işbirliği ve güven ilişkilerini de geliştirmek için çaba sarf eder. Yeni kamu hizmetinde vatandaş unsuru önemlidir. Vatandaş, ne geleneksel kamu yönetiminin önerdiği gibi bağımlı bireydir ne de yeni kamu yönetimi yaklaşımının ifadesindeki gibi sadece kendi çıkarı için hareket eden bir müşteridir. Vatandaş, hak ve yükümlülükleri olan, siyasal sisteme etki etme gücüne sahip bireydir. Devletle vatandaşları arasındaki ilişkiyle, şirketle müşterisi arasındaki ilişki aynı değildir. Devlet sadece müşterilere hizmet verirse o zaman parası olan daha çok ve daha nitelikli hizmetler alabilirken parası olmayan bu hizmetleri 
alamayacaktır; bu durum ise kamusal hizmet sunumunda eşitlik ve adalet anlayışıyla bağdaşmayacaktır. Devlet kamusal hizmeti talep eden ve ihtiyacı olup maddi gücü olmayan herkese hizmet sunar. Hatta talep edilmese dahi hizmet sunar.

-Hesap verebilirlik: Kamu çalışanı, özel sektördeki çalışanlardan daha dikkatli olmalı; vatandaşların çıkarlarına, politik kurallara, profesyonellik standartlarına, toplumsal değerlere, anayasaya ve yasalara uygun davranmak zorundadır. Bunu yaparken kamu çalışanları geniş tabanlı vatandaş katılımıyla ve iletişimle vatandaşların taleplerini karşılamaya ve onların sorunlarını çözmeye çalışmalıdır. Bunlarla birlikte müzakere süreci oluşturulabilir, aktif vatandaşlık ve hesap verebilirlik güçlendirilebilir.

-İnsana değer vermek: Yeni kamu hizmeti, insanlarla birlikte yönetme anlayışına önem vermektedir. Eğer toplumsal değerler ve çıkarlar yeterince göz önünde bulundurulmazsa, üretimin iyileştirilmesi, sürecin yeniden yapılandırılması ve performans ölçümü uzun dönemde başarısız olacaktır. Bu nedenle kamu hizmetlerinin sunumunda sorumlu, vatandaşı düşünen ve sürece dahil eden bir yaklaşımla hareket edilmelidir.

-Vatandaşlık ve kamu hizmeti girişimcilikten daha önemlidir: Kamu çıkarı, devletin parası kendilerininmiş gibi hareket eden girişimci ruhlu yöneticilerden ziyade, topluma anlamlı katkılar sunmayı amaçlayan kamu çalışanları ve vatandaşlar tarafından daha iyi geliştirilebilir. Yeni kamu hizmeti anlayışına göre; kamu yöneticileri yalnızca gücü paylaşıp insanlarla beraber çalışmamalı, aynı zamanda yönetişim süreci içinde girişimci değil, birer sorumlu paydaş olduklarını unutmamak durumundadırlar. Yeni kamu hizmetinde kamu yöneticilerinin kurumlarının, programlarının ve kamu kaynaklarının sahipleri olmadığı açıkça kabul edilmektedir. Devlet, vatandaşlara ait olan bir kurumdur.

Yeni kamu hizmeti yaklaşımında kamu idarecileri hiyerarşiye, katı kurallara dayalı, kendisine has uzmanlık jargonuna sahip bürokratik yapılanmadan kurtularak toplum ve vatandaşlar için düşünmeli ve hareket etmelidir. Kamu idarecileri kazandıkları tecrübeleri vatandaşla paylaşmalı onu bilgilendirmelidir, yetkilendirmelidir ve en önemlisi onların ihtiyaçlarına, beklentilerine değer vermelidir. Kamu idarecilerinin yardımları ve cesaretlendirmeleri sonucunda vatandaşlar yönetime katılabilecek duruma gelmelidir (Zengin, 2008: 35).

Kamu yönetiminde bir dönüşümün yaşandığı ve devletin rolünün dümen tutmaktan hizmet sunmaya doğru değiştiği gözlenmektedir (Ütük, 2015: 63). Kamu çalışanlarının müşterilerin değil vatandaşların taleplerine karşılık verdiği bu durumda kamu çıkarı anlayışı da değişmiştir çünkü öncesinde hukuk kurallarıyla ifade edilen kamu çıkarı ilk olarak kişisel faydaların bütünü olarak değerlendirilmiş sonrasında ise paylaşılan değerlere ilişkin bir uzlaşı halinde kabul görmeye başlamıştır (Ütük, 2015: 63-64). Kamu çalışanları artık topluma kamu hizmeti sunma isteği ile motive olmaktadır (Ütük, 2015: 64). Kamu politikaları ve programları uzlaşı sonucu ortaya çıkan ihtiyaçlar doğrultusunda kamu yararı gözetilerek oluşturulmaktadır (Ütük, 2015: 64). Kamu yöneticileri ise hesap verebilirlik anlayışı çerçevesinde işlerini yapar hale gelmiş ve bu hesap verebilirlik sadece 
hukuku değil toplumsal değerleri ve vatandaşların menfaatlerini de göz önünde bulundurur hale gelmiştir (Ütük, 2015: 64).

\subsection{Yeni Kamu Hizmeti Anlayışının Yönetişim Kavramı ile İlişsisi}

Yeni kamu hizmeti yaklaşımı yönetişim kavramını, iletişimi ve etkileşimi sürekli olarak ön planda tutmaktadır. Hatta yeni kamu hizmetinin katılımcı modelin yeni şekli olduğu ifade edilmektedir (Güler, 2005: 6). Denhardt'ın desteklediği yönetişimci yeni kamu hizmeti ise mali sermayenin para piyasalarındaki hareket felsefesine koşut bir toplum idaresi yapılanmasına meyilli durmaktadır (Güler, 2005: 6). Yeni kamu hizmeti yaklaşımının kısmen bazı temellerini oluşturan yeni kamu yönetimi anlayışının ise 1980 sonrası süreçte kendini gösteren demokratikleşme, sivil toplum ve yönetişim anlayışlarının üzerine konumlandığı (Genç, 2010: 147) ve dolayısıyla yeni kamu hizmeti yaklaşımının da faydalı gördüğü bu anlayışlardan etkilendiği ifade edilebilir. Yeni kamu hizmeti yaklaşımı demokratik değerlerin yönetişim anlayışı çerçevesinde yüceltilmesi gerektiğini ortaya koymaktadır (Genç, 2010: 158). Yönetişim anlayışı çerçevesinde devletin hesap verebilir, saydam, katılımcı, sivil toplumu idare sürecine katan, kar ve kamu yararı, müşteri ve vatandaş ilişkilerini en iyi seviyede tutan bir şekle bürünmesi gerektiği ifade edilmektedir (Arslan, 2010: 35-36). Yeni kamu hizmeti yaklaşımı da benzer şekilde hesap verebilirlik, yönetimde ve kamu hizmetlerinin sunumunda katılımcıllk kavramlarını öne çıkarmakla beraber kamu yararı ve vatandaş kavramlarını kar ve müşteri kavramlarını önüne koymaktadır. Ayrıca yönetişim mekanizması kullanılarak ve dolayısıyla halkın katılımı sağlanarak yönetimdeki sorunların aş1labileceği ifade edilmektedir (Atmaca, 2012: 28). Bu noktada yönetişimin, yani kamu hizmeti sunumunda ve kamunun idaresinde vatandaşların da katılımıyla birlikte, vatandaşları daha çok memnun edeceği söylenebilir. Yönetişimin bir kural sistemi değil bir süreç olduğu, egemenlik üzerine değil anlaşma üzerine kurulduğu, kamu ve özel sektör aktörlerini aynı anda içinde barındırdığı ve resmi bir kurum olmaktan ziyade devamlı etkileşime bağlı bir süreç olduğu literatürde belirtilmektedir (Atmaca, 2012: 36). Yeni kamu hizmetinin temellerinin bir kısmını yönetişim kavramı içerisinde görmek mümkündür. Yönetime aktif katılımın vatandaşlık için artık daha önemli olduğu ve kamu hizmetlerinde aktif vatandaşlı̆ı̆ın etkisinin hissedildiği konusu yönetişim kavramıyla doğrudan ilgilidir (Uysal, 2013: 1). Vatandaşın ön planda tutulduğu yeni kamu hizmeti anlayışı için yönetişim kavramının bir hayli önemli olduğu ve devletlerin vatandaş taleplerini ön planda tutarak ve yönetişim uygulamalarıyla onlarla birlikte kararlar vererek (Uysal, 2013: 13-14) onları da kamu hizmetleri ve kamu idaresi süreçlerine dahil ettiği söylenebilir.

Sonuç olarak yönetişim kavramı yeni kamu hizmeti yaklaşımının sacayaklarından birisini oluşturmaktadır. Yönetişim kavramının temel ilkelerden biri olarak kabul edilmesi yeni kamu hizmeti yaklaşımının vatandaş odaklı olduğunun da bir göstergesidir. 


\subsection{Yeni Kamu Hizmeti Anlayışının Odak Noktası Olan Vatandaşa Yaklaşımı}

Yeni kamu hizmeti anlayışı vatandaşı merkeze alarak ve vatandaşları memnun etmek için kamu yararını temel alan bir yaklaşım içerisindedir. Kamu hizmetlerinde kamu yararının temel amaç olması vatandaş odaklı bir anlayışın da göstergesidir. Bir kamu hizmetinin sunumunda yapılacak her türlü faaliyetlerden toplumun zarar görmemesi veya en az zarar görecek şekilde yapıllyor olması o hizmetin yapılmasında kamu yararının bir ölçüt olduğunun göstergesidir denilebilir (Sezer, 2008: 156). Hatta bir hizmetin sunumunda kamu yararı temel ölçüt olarak ele alınıyorsa ilgili hizmet nitelikli bir kamu hizmeti olmasa dahi sunulması gerekmektedir (Sezer, 2008: 157). Dolayısıyla kamu yararı herhangi bir kamu hizmetinin sunumunda ilgili kitleyi müşteri olarak değil vatandaş olarak görmek durumundadır (Sezer, 2008: 157). Vatandaşın ön plana çıkmasında düşük ve yüksek vatandaşlık anlayışlarının etkisinin olduğu literatürde ifade edilmektedir. Düşük yurttaşlık kavramında otorite hiyerarşik olarak dağılmakta ve en tepede bulunanlar otoritenin büyük kısmını ellerinde tutmaktadırlar (Kantarcıoğlu, 2016: 46). Yüksek yurttaşlık kavramında ise güç ve otoritenin büyük oranda dağıtıldığ1 ve vatandaşların otorite bölüşümünde eşit bir şekilde yer alması gerektiği ifade edilmektedir (Kantarcıoğlu, 2016: 46). Denhardt'ların yeni kamu hizmeti anlayışını oluştururken yüksek yurttaşlık tanımına daha yakın durduğu ifade edilebilir çünkü vatandaşların kamu hizmetlerine ve yönetime aktif katılımı, kamu yararı, toplumun çıkarlarının ön planda tutulması, devlet işlerine ilgi duyulması, demokrasi ve kamusal işlere aktif katılım yeni kamu hizmeti anlayışının temel prensiplerindendir (Kantarcioğlu, 2016: 46).

Yeni kamu yönetimi anlayışının vatandaşa müşteri olarak yaklaşması sürekli olarak literatürde eleştirilmektedir. $\mathrm{Bu}$ eleştiriler devletin esas sahibi olan vatandaşın müşteri olarak görülmesine anlayışına yapılmaktadır. Örneğin Türkiye'de son dönemde üniversite harçları kaldırılmış ve vatandaşlar üniversite eğitimi sırasında hiçbir ücret ödememişlerdir (ikinci öğretim öğrencileri bunun dışında). Daha öncesinde ise her öğrenci her ders yılında kayıt yenilerken bir miktar ücret yatırmaktaydı. Bu harçların miktarı çok yüksek olmamakla birlikte devlet tarafından sunulan bir kamu hizmetinden hiçbir şekilde ücret alınamayacağı anlayışının yeni durumda kendini göstermiş olduğunu söyleyebiliriz. Diğer bir örnek ise önceleri mahalle muhtarlarından belirli ücretler karşılığında alınan evraklar konusudur. Şimdi ise uygulamada insanlar hiçbir ücret ödemeden nüfus dairlerinden ilgili evrakları temin edebilmektedir. Hatta e-devlet uygulamalarıyla birlikte ek hiçbir zahmet göstermeden sistem üzerinden öğrenci belgesi, askerlik durum belgesi, adliyelerden alınan temiz belgesi ve daha birçok belgeye ücret ödemeden ve hatta herhangi bir yol vs. zahmetine katlanmadan erişilebilmektedir. Bu durum devletin vatandaşı müşteri olarak gördüğü algısının değiştiğini, sunulan kamu hizmetlerinde amacın kamu yararı olduğunu ve vatandaşa vatandaş olduğu için hizmet sunulduğunu göstermektedir. $\mathrm{Bu}$ algının değişmesinin sebeplerinden birisi vatandaşların kamu hizmetlerinden memnuniyetini ve dolayısıyla devlete olan memnuniyetini arttırmayı amaçlamaktır. Sosyal devlet algısının da bu noktada önemli olduğu ifade edilebilir. Ayrıca iktidardaki hükümetlerin oy kaygısıyla bu tarz hareketlerde bulundukları da ifade edilebilmektedir. Devletin kamu hizmetlerinin sunumunda ve kamunun 
idaresinde vatandaştan aktif katılım istemesi yeni kamu hizmeti yaklaşımı için temel oluşturmaktadır. $\mathrm{Bu}$ konuya eleştirel bir bakış açısıyla da yaklaşmak gerekebilir. Yeni kamu yönetimi anlayışında vatandaşa müşteri gözüyle bakılıyordu. Vatandaş yani 'müşteri' her zaman haklıdır yaklaşımından hareketle yapılan hizmetlerin eksiklikleri eleştiriliyor ve dahası müşteri olarak yaklaşılmasına ve özel sektör mantığıyla hareket edilmesine rağmen memnuniyetsizlikler, başarısızlıklar ve yanlış uygulamalar ortaya çıkabiliyordu. Devlet üzerindeki sorumluluğu paylaşmak, yönetim ve hizmet yükünün bir kısmını da vatandaşa devrederek kendi yükünü azaltmak için bu tarz uygulamalara gidebilir. Yönetime, kamu politikalarının yapılması ve uygulanmasına, kamu hizmetlerinin sunulmasına vatandaşın aktif katılımını yeni kamu hizmeti anlayışı vurgulamaktadır fakat bu noktada vatandaş da sorumluluk sahibi yapılarak devlet uygulanan politikalardaki eleştirilerden kurtulmaktadır. Çünkü sorumluluğun sahibi artık sadece devlet değildir. Dolayısıyla vatandaşla etkileşim ve vatandaş odaklı hareket etmek vatandaşlarda memnuniyeti arttıracağı gibi yapılan yanlış işlerde de sorumluluk paylaştırılarak devlet eleştirilerden kurtulmaktadır. Algının müşteriden vatandaşa dönüşmesinin en büyük sebebi rasyonel ve çıkarcı olduğu söylenen bireylerin devletten memnuniyetinin arttırılması ve uygulanmakta olan kamu politikalarının ve sunulmakta olan kamu hizmetlerinin bireyler üzerindeki memnuniyetini arttırmaktır. Çünkü devlet sorumluluğu ve üzerindeki yükü paylaşarak vatandaşı artık ilgili kamu hizmetlerine itiraz edemez bir hale getirmektedir. Dahası vatandaşın aktif katılımıyla birlikte uygulanan politikalarda vatandaşın da bir sorumluluğunun olduğu hissettirilerek ortada bir yanlış veya eksik olması durumunda bunun sadece devletin değil tüm vatandaşların bir hatası olduğunun ifade edilmesidir.

Yeni kamu hizmeti anlayışında: "Kamu yararı bireysel çıkarların toplamından ziyade paylaşılan değerler hakkındaki diyalogdan doğar. Bu nedenle kamu görevlileri sadece müşterinintüketicinin taleplerine cevap vermek değil, vatandaşlar arasında güven ve işbirliğini tesis etmek üzerine odaklanmalıdır. Yeni kamu hizmetinde vatandaş vurgusu önemlidir. Vatandaş, ne geleneksel kamu yönetimi anlayışının önerdiği gibi bağımlı bireydir ne de yeni kamu yönetiminin önerdiği gibi kendi çıkarının peşinde koşan müşteridir. Vatandaş, hak ve yükümlülüklere sahip, siyasal sisteme etki etme gücüne sahip bireydir." (Genç, 2010: 155) şeklinde yaklaşımlar mevcuttur.

Yönetişim kavramının son dönemde moda haline gelmesiyle birlikte vatandaşlık kavramı da ön planda olmaya başlamıştır. Politika yapım süreçlerine katılan ve rol alan, doğrudan demokrasiyi kullanan vatandaş kavramı kendini göstermiştir (Uysal, 2013: 107). Demokratik vatandaşlık kavramı kendi çıkarından ziyade kamu yararını düşünen, kamu işleri hakkında bilgili olan ve bunların yürütülmesine dahil olmayı gaye edinen bir vatandaşlık tanımını ifade etmektedir (Uysal, 2013: 107). Bu noktada vatandaş toplum için gayret göstermekte ve bu vatandaşlara topluma hizmet etme yönünde görev ve sorumluluk yüklenmektedir (Uysal, 2010: 107). 2000'li yıllarla birlikte toplumlar daha verimli yönetişim biçimleri ortaya koymakta ve böylece yeni bir vatandaşlık bilinci kendini göstermektedir (Uysal, 2013: 109). Bu anlayışta ise vatandaş kendi sorunlarına sahip çıkan, yüksek standartlar talep eden ve bu standartların üretilmesinde ve uygulanmasında aktif rol alan bir hale 
gelmiştir (Uysal, 2013: 109). Tabi bu durumun ortaya çıkmasında devletlerin kalitesi, yaşam kalitesi, politik rejim kalitesi ve toplumların kalitesi de belirleyici olmaktadır (Uysal, 2013: 110). Yeni kamu hizmetinin vatandaş yaklaşımı da bu şekilde ortaya çıkmıştır.

Diğer taraftan vatandaşın müşteri olarak görülmesinde sorunlar ortaya çıkmaktadır. Örneğin, vatandaş müşteri olarak görülürse emniyet hizmetinin, adalet mekanizmasının veya ülke savunmasının müşterileri kimdir sorusu akla gelecek ve net bir cevap verilemeyecektir. Ayrıca müşteri piyasadaki ürünler arasından seçim yaparken vatandaş hangi hizmetlerin kendileri için önemli olduğunu belirtip bunların devlet tarafından sunulmasını sağlamaktadır (Uysal, 2013: 113). Müşteri ve vatandaş arasındaki bir karmaşıklık da vergi ödeme noktasında ortaya çıkmaktadır. Tüm vatandaşlar kendilerine yüklenen vergileri ödemektedir ve böylece hali hazırda ödedikleri vergilerin karşıllğında bir hizmet almak durumundadırlar. Ayrıca bir ücret ödemek onları vatandaşlıktan müşteriliğe götürmektedir. Bu noktada kamu yararı kavramı da hasar görmektedir. Zaten vergilerini ödeyen vatandaşlara hizmet sunulurken birde onlardan fazladan ücret talep edilerek bazı hizmetlerin sunulması kamu yararından ziyade kar amacının taşındığını göstermektedir. Bu noktada devletin vazifesinin ne olduğu sorusu akla gelmektedir. Müşterilere ücret karşı1lı̆̆ daha iyi hizmetler sunmak mı? Yoksa üzerlerine yüklenen tüm vergileri ödeyen ve devletin esas sahibi olan vatandaşlara ekstra ödeme olmadan hizmet sunup kamu yararını sağlamak mı? Ayrıca tüm vatandaşlar kamu hizmetlerinden faydalanabilmektedir. Yani daha fazla karakola giden, daha fazla adliyeye giden, daha fazla hastaneye giden veya daha çok eğitim alan vatandaşlar fazla vergi ödememektedir. Çünkü kamusal hizmetler paylaştırılamaz ve parayla ölçülemez. Kamu yararı tüm toplum içindir. Dolayısıyla daha zengin olan da daha fakir olan da istediği kadar kamu hizmeti alabilecektir. Ondan dolayı kamu hizmetlerin de ve kamu yararı meselesinde eşitsizlik diye bir durumun ortaya çıkmasının mümkün olmaması gerekmektedir.

Sonuç olarak yeni kamu hizmeti anlayışı kamu yararını ve vatandaşın aktif katılımını kendisine temel esas olarak kabul etmektedir. Müşteri yaklaşımını çok doğru bir anlayış olarak benimsememektedir.

3.Geneleksel Kamu Yönetimi ve Yeni Kamu Yönetimi Anlayışı ile Yeni Kamu Hizmeti

\section{Anlayışıııı Karşılaştırılmasıı}

Geleneksel kamu yönetimi, yeni kamu yönetimi ve yeni kamu hizmeti yaklaşımlarının karşılaştırılmasını bir tablo ile kısa ve öz bir şekilde ortaya koyabiliriz (Tablo 1'e bakınız). 
Tablo 1: Karşılaştırmalı Bir Bakış Açısılla Geleneksel Kamu Yönetimi, Yeni Kamu Yönetimi ve Yeni Kamu Hizmeti Yaklaşımları

\begin{tabular}{|c|c|c|c|}
\hline & $\begin{array}{l}\text { Geleneksel Kamu } \\
\text { Yönetimi }\end{array}$ & $\begin{array}{l}\text { Yeni Kamu } \\
\text { Yönetimi }\end{array}$ & Yeni Kamu Hizmeti \\
\hline $\begin{array}{l}\text { Temel teorik ve } \\
\text { epistemolojik } \\
\text { dayanaklar }\end{array}$ & $\begin{array}{l}\text { Siyasal teori, sosyal } \\
\text { bilimler tarafından } \\
\text { artarak yapılan sosyal } \\
\text { ve siyasal yorumlar }\end{array}$ & $\begin{array}{l}\text { Ekonomik teori, } \\
\text { pozitivist sosyal } \\
\text { bilime dayanan daha } \\
\text { gelişmiş diyalog }\end{array}$ & $\begin{array}{l}\text { Demokratik teori, yorumlayıcı, } \\
\text { eleştirel, pozitif içeriği olan } \\
\text { bilgiye farklı yaklaşım }\end{array}$ \\
\hline $\begin{array}{l}\text { İnsan davranışlarına } \\
\text { hakim olan mantık } \\
\text { ve buna ilişkin } \\
\text { modeller }\end{array}$ & $\begin{array}{l}\text { "Yönetsel insan" } \\
\text { (administrative man) }\end{array}$ & $\begin{array}{l}\text { Teknik ve ekonomik } \\
\text { mantıksalık, } \\
\text { “ekonomik insan” }\end{array}$ & $\begin{array}{l}\text { Stratejik ya da biçimsel } \\
\text { mantıksallık, mantıksallığın farklı } \\
\text { açılardan (örgütsel, politik, } \\
\text { ekonomik) test edilmesi }\end{array}$ \\
\hline $\begin{array}{l}\text { Kamu yararı } \\
\text { Kavramı }\end{array}$ & $\begin{array}{ll}\text { Politik } & \text { olarak } \\
\text { tanımlanmış, } & \\
\text { Hukuksal } & \text { olarak } \\
\text { belirlenmiştir. } & \end{array}$ & $\begin{array}{lr}\text { Bireysel } & \text { yararların } \\
\text { bütününü } & \text { temsil } \\
\text { etmekte } & \end{array}$ & $\begin{array}{l}\text { Paylaşılan değerler hakkındaki } \\
\text { bir uzlaşımın sonucu }\end{array}$ \\
\hline $\begin{array}{l}\text { Kamu hizmeti } \\
\text { Sunanların } \\
\text { sorumluluğu }\end{array}$ & $\begin{array}{l}\text { Hizmeti alanlara ve } \\
\text { tamamlayıcılarına }\end{array}$ & Müşterilere & Vatandaşlara \\
\hline Yönetimin rolü & $\begin{array}{l}\text { "Dümen tutmak değil, } \\
\text { kürek çekmek" }\end{array}$ & “Dümen tutmak" & $\begin{array}{l}\text { “Hizmet” etmek, topluluk ve } \\
\text { gruplar arasında çıkarlara aracılık } \\
\text { ve müzakere etmek }\end{array}$ \\
\hline $\begin{array}{l}\text { Politika } \\
\text { amaçlarının } \\
\text { başarılmasındaki } \\
\text { mekanizmalar }\end{array}$ & $\begin{array}{l}\text { Yönetim kuruluşları } \\
\text { Aracılığıyla programları } \\
\text { gerçekleştirmek }\end{array}$ & $\begin{array}{l}\text { Özel ve kar amacı } \\
\text { gütmeyen kuruluşlar } \\
\text { aracılığıyla politika } \\
\text { amaçlarını başarmak } \\
\text { için özendirici yapılar } \\
\text { ve mekanizmalar } \\
\text { oluşturmak. }\end{array}$ & $\begin{array}{l}\text { Karşılıklı bir şekilde anlaşılan } \\
\text { ihtiyaçların temini için özel } \\
\text { kuruluşlar, kar amacı gütmeyen } \\
\text { organizasyonlar ve kamudan } \\
\text { oluşan bir koalisyon ile } \\
\text { paylaşılan değerleri oluşturmak. }\end{array}$ \\
\hline $\begin{array}{l}\text { Hesap } \\
\text { verebilirliğe } \\
\text { yaklaşım }\end{array}$ & $\begin{array}{l}\text { Hiyerarşik- Yöneticiler } \\
\text { demokratik olarak } \\
\text { seçilmiş siyasal liderlere } \\
\text { sorumludur }\end{array}$ & $\begin{array}{l}\text { Piyasa yönlendirmesi } \\
\text { kişisel yararların } \\
\text { toplamı geniş } \\
\text { vatandaş } \\
\text { ya da müşteri grupları } \\
\text { tarafından istenen }\end{array}$ & $\begin{array}{l}\text { Çok çeşitli yüzlere sahip, kamu } \\
\text { görevlileri hukuk, topluluk } \\
\text { değerleri, siyasal kurallar ve } \\
\text { vatandaş çıkarları konularıyla } \\
\text { ilgilidirler. }\end{array}$ \\
\hline
\end{tabular}




\begin{tabular}{|c|c|c|c|}
\hline & & çıktıların sonucudur. & \\
\hline $\begin{array}{l}\text { Yönetsel takdir } \\
\text { Yetkisi }\end{array}$ & $\begin{array}{l}\text { Yönetsel birimlere } \\
\text { sınırlı takdir yetkisi } \\
\text { verilmekte }\end{array}$ & $\begin{array}{l}\text { Girişimci amaçların } \\
\text { karşılanması için } \\
\text { serbestlik. }\end{array}$ & $\begin{array}{l}\text { Takdir yetkisi gerekli ancak } \\
\text { sınırlanmış ve hesap verilebilir } \\
\text { bir şekilde }\end{array}$ \\
\hline Örgütsel yapı & $\begin{array}{l}\text { Kuruluşlar için belirli } \\
\text { bir otoritenin olduğu } \\
\text { bürokratik } \\
\text { örgütlenmeler }\end{array}$ & $\begin{array}{l}\text { Kuruluşlarda öncelikli } \\
\text { denetimin olduğu } \\
\text { desantralize edilmiş } \\
\text { kamu } \\
\text { organizasyonları }\end{array}$ & $\begin{array}{l}\text { Liderliğin içsel ve dışsal olarak } \\
\text { paylaşıldığı işbirliği yapıları }\end{array}$ \\
\hline $\begin{array}{l}\text { Kamu çalışanları ve } \\
\text { yöneticilerinin } \\
\text { motivasyon } \\
\text { kaynakları }\end{array}$ & $\begin{array}{l}\text { Ödeme ve çıarlar, } \\
\text { kamu görevi güvencesi }\end{array}$ & $\begin{array}{l}\text { Girişimci ruh, devletin } \\
\text { boyutunu küçültmek } \\
\text { için ideolojik arzu }\end{array}$ & $\begin{array}{l}\text { Kamu hizmeti, topluma yardım } \\
\text { etme (katkı yapma) isteği }\end{array}$ \\
\hline
\end{tabular}

Kaynak: -Robert B. Denhardt and Janet Vinzant Denhardt, The New Public Service: Serving Rather Than Steering, Public Administration Review, Vol. 60, No. 6 (Nov. - Dec., 2000), pp. 549-559,

-Janet Vinzant Denhardt and Robert B. Denhardt (2007), The New Public Service: Expanded Edition Serving, Not Steering, pp. 28-29, M.E. Sharpe, Inc. London.

Sonuç olarak, yeni kamu hizmeti anlayışı vatandaşı düşünen, kamu yararını hedefleyen, karşılıklı etkileşimlerle şekillenen bir uzlaşı sonucu ortaya çıkan yönetim ve kamu hizmeti anlayışını ifade etmektedir. Geleneksel kamu yönetimi katı, kuralc1, bürokratik yapısıyla yeterince eski ve kullanılamaz bir hale gelmiştir. Yeni kamu yönetimi anlayışının ise vatandaştan ziyade piyasayı, girişimciliği, müşteriyi, serbestliği hedeflediği, kürek çekmekten veya hizmet etmekten ziyade sadece dümende durmak istediği ifade edilmiştir. Fakat yeni kamu hizmeti anlayışı bu iki köklü yaklaşımın bir basamak üstüne çıkarak kürek çekme ve dümen tutma anlayışından vazgeçip hizmet etme anlayışını kendine temel ilke olarak kabul etmiştir.

\section{Sonuç}

Geleneksel kamu yönetimi anlayışı yıllarca kullanılmış fakat değişen ve dönüşen toplumsal koşullara ayak uyduramaz bir hale gelmiştir. İnsanların ve toplumların ihtiyaçları değişmiş, devletten aldıkları kamu hizmetinin kalitesinin, hızının ve çeşitliliğinin de bu doğrultuda değişmesi gerektiği düşüncesi ortaya çıkmıştır. Vatandaşlar kendilerine sunulan kamu hizmetinin ilk zamanlardaki tek tipliğinden, kalitesizliğinden, yavaşlı̆̆ından ve kendilerine karşı kamu görevlilerinin tavrından memnun olmadıklarını yıllardır dile getirmektedirler. Geleneksel kamu yönetimi anlayışı bu tepkiler sonucunda tam anlamıyla olmasa da bir değişim ve dönüşüm geçirmiştir. Bu dönüşüm yeni kamu yönetimi akımının ortaya çıkmasıyla meydana gelmiştir. Yeni kamu yönetimi anlayışı devletin özel sektör tekniklerini kullanarak işleri yürütmesi gerektiğini ve kamu hizmetlerini de bu şekilde üretip sunması gerektiğini ifade etmiştir. Vatandaşa artık müşteri gözüyle bakılmakta, kamu çalışanları bir 
özel sektör personeli gibi performans kriterlerine tabi tutulmakta, kamunun örgüt yapısı özel sektöre benzer şekilde değişimler geçirmekte ve kamu hizmetleri de bu mantıkla üretilip sunulmaya çalışılmaktadır. Etkinlik, verimlilik, performans, girişimcilik gibi özel sektöre ait yönetim esasları kamu yönetimine aktarılmaya çalışılmakta ve kamu hizmeti de bu ilkeler kullanılarak üretilmektedir. Fakat vatandaşa müşteri gözüyle bakılması, kullanan öder gibi varsayımların ortaya atılması esasen devletin asıl sahibi olan vatandaşta memnuniyetsizlik yaratmıştır. Demokrasinin güçlendirilmesi, yönetişim kavramının kamu yönetiminin ve kamu hizmetlerinin içine iyiden iyiye yerleşmesi, sivil toplum kuruluşlarının daha etkin ve yaygın hale gelmesi, kişiden kişiye değişen ihtiyaçların ortaya çıkması ve bunların giderilmesinin gerekliliği, devletin kuruluş amacı olan vatandaşın ön plana alınması gibi yaklaşımlar yeni kamu hizmetinin temellerinin atılmasında etkin rol oynamıştır. Etkinlik, girişimcilik gibi kavramlardan ziyade kamu yararının ön plana çıkması, kamu çalışanlarının kendilerinin çıarlarından ziyade toplumun faydasını gözetmesi, hesap verilebilirlik kavramının önemi, vatandaşın yönetime müdahil olması ve hizmet sunumunda aktif rol alması, uzlaşı ve diyalog kültürünün oluşması, dümen tutmaktansa hizmet etmenin ön plana çıkması gibi yaklaşımlar yeni kamu hizmeti anlayışının önemli ilkelerindendir.

Özetlemek gerekirse, hızla değişen hayat koşulları ve toplumsal ihtiyaçlar geleneksel ve yeni kamu yönetimi anlayışlarının kamu hizmetlerinin sunumunda yetersiz kaldığını ortaya çıkarmıştır. Bu noktada devreye giren yeni kamu hizmeti anlayışı vatandaşın memnuniyetini ve kamu yararını odak noktası yaparak kamu hizmetlerinin sunumunda bir anlayış ortaya koymuştur. Bu anlayışla kamu hizmetlerinin sunumunun önemli bir unsuru olan vatandaşların daha memnun olacağı ortadadır. 


\section{Kaynakça:}

Arslan, Nagehan Talat (2010) "Klasik - Neo Klasik Dönüşüm Süreci: Yeni Kamu Yönetimi”, C.Ü. İktisadi ve İdari Bilimler Dergisi, C. 11, S. 2, ss. 21-38.

Atmaca, Yıldız (2012) Yeni Kamu Yönetimi Anlaylşı Çerçevesinde Belediyelerde Kamu Hizmet Anlayışı Değişimi: Konya Büyükşsehir Belediyesi Örneği, Selçuk Üniversitesi Sosyal Bilimler Enstitüsü Kamu Yönetimi Ana Bilim Dalı, Yüksek Lisans Tezi, Konya.

Aydın, Abdurrahman (2013) Yeni Bir Kamu Hizmeti Sunma Yöntemi Olarak M-Devlet: Kamu Yönetimi Alanında Uygulama Alanları ve Etkinliği, Kahramanmaraş Sütçü İmam Üniversitesi Sosyal Bilimler Enstitüsü Kamu Yönetimi Ana Bilim Dalı, Yüksek Lisans Tezi, Kahramanmaraş.

Çakır, Meryem (2014) 1980 Sonrası Kamu Hizmeti Kavramının Dönüşümü Üzerine Bir İnceleme, Ankara Üniversitesi Sosyal Bilimler Enstitüsü Siyaset Bilimi ve Kamu Yönetimi Ana Bilim Dalı, Yüksek Lisans Tezi, Ankara.

Denhardt, Janet V. ve Robert B. Denhardt (2007) The New Public Service Expanded Edition: Serving, Not Steering, M.E. Sharpe Inc., London.

Denhardt, Robert B. ve Janet Vinzant Denhardt (2000) "The New Public Service: Serving Rather Than Steering”, Public Administration Review, C. 60, S. 6, ss. 549-559.

Ersöz, Deniz (2010) Değişen Devlet Dönüşen Sağllk: Kamu İşletmeciliği ve Politika Transferi Bağlamında Sağllkta Dönüşüm Programı, Balıkesir Üniversitesi Sosyal Bilimler Enstitüsü Kamu Yönetimi Ana Bilim Dalı, Yüksek Lisans Tezi, Balıkesir.

Eryılmaz, Bilal (2010) Kaти Yönetimi: Düşünceler Yapılar Fonksiyonlar, Okutman Yayıncılık, Ankara.

Genç, F.Neval (2010) "Yeni Kamu Hizmeti Yaklaşımı”, Türk İdare Dergisi, S. 466, ss. 145-159.

Güler, Birgül A. (2005) "Kamu Yönetimi Yaklaşımları Nasıl Sınıflandııılabilir?”, Yaklaşımları Sınıflandırmak, Çalışma notu, sf. 1-7.

Güngör, Mustafa (2010) Kamu Hizmeti Anlaylşındaki Dönüşümlerin Türkiye'de Kamu Personeli Saylsına ve Bileşimine Etkileri, Hacettepe Üniversitesi Sosyal Bilimler Enstitüsü Siyaset Bilimi ve Kamu Yönetimi Ana Bilim Dalı, Yüksek Lisans Tezi, Ankara.

Habermas, Jürgen (2004) "Kamusal Alan” (Çev. Meral Özbek), Meral Özbek (Ed.); Kamusal Alan, Hil Yayın, İstanbul, ss. 95-102.

Hasdemir, Tuba Asrak ve Mustafa Kemal Coşkun (2008) "Kamusal Alan ve Toplumsal Hareketler", Ankara Üniversitesi SBF Dergisi, C. 63, S. 1, ss. 121-149.

Kantarcıŏglu, Meryem Çakır (2016) "Eleştirinin Eleştirisi: Yeni Kamu Hizmeti Yaklaşımının Yurttaş Bakışına Dair Bir İnceleme”, Emek Araştırma Dergisi (GEAD), C. 7, S. 9, ss. 43-56.

Karadağ, Ahmet (2003) "Kamusal Alan Modelleri: Çoğulcu Perspektiften Bir Değerlendirme", Ankara Üniversitesi SBF Dergisi, C. 58, S. 3, ss. 171-195.

Kavruk, Hikmet (2002) Anakent'e Bakış - Türkiye'de Anakent Belediyeciliği ve Kent Hizmetlerinin Yönetimi, Hizmet-İs Sendikası, Ankara.

Korkut, Gülsüm, Osman Kürşat Acar ve Alim Tetik (2015) "Yeni Kamu Yönetimi Anlayışı ile Değişen Kamu Hizmeti ve Türkiye İş Kurumu”, İ̧̧ ve Hayat Dergisi, S. 2, ss. 107-135.

Müftüoğlu, Zeynep (2011) Bir Kamu Hizmeti Olarak Su Kaynakları Yönetimi, Ankara Üniversitesi Sosyal Bilimler Enstitüsü Kamu Hukuku Ana Bilim Dalı, Yüksek Lisans Tezi, Ankara.

Ökmen, Mustafa ve Fatih Demir (2010) "Kamu Hizmetinin Felsefi Temelleri ve Yeni Kamu Yönetiminde Geçirdiği Dönüşüm”, Süleyman Demirel Üniversitesi IIIBF Dergisi, C.15, S.3, ss.19-42.

Özbek, Meral (2004) “Giriş: Kamusal Alanın Sınırları”, Meral Özbek (Ed.); Kamusal Alan, Hil Yayın, İstanbul, ss. $19-89$.

Özcan, Kerim ve Veysel Ağca (2010) "Yeni Kamu Yönetimi Anlayışında Postmodernizmin İzleri”, Amme İdaresi Dergisi, C. 43, S. 3, ss. 1-32.

Özer, M. Akif (2005) “Günümüzün Yükselen Değeri: Yeni Kamu Yönetimi”, Saylştay Dergisi, S. 59, ss. 3-46. 
Sezer, Özcan (2008) "Kamu Hizmetlerinde Müşteri (Vatandaş) Odaklılık: Türkiye’de Kamu Hizmeti Anlayış1 Açısından Bir Değerlendirme”, ZKÜ Sosyal Bilimler Dergisi, C. 4, S. 8, ss. 147-171.

Taş, İ. Ethem ve Ahmet Hamdi Aydın (2010) “Küreselleşme, Kamu Yönetimi ve Kamu Hizmeti”, Ahmet Hamdi Aydın, İ. Ethem Taş, Meltem Kılıç ve Zehra Gül (Ed.); Küreselleşme Karşısında Kamu Yönetimi ve Hizmeti, Kahramanmaraş Sütçü İmam Üniversitesi, Kahramanmaraş, ss.3-8.

Uysal, Özge (2013) Vatandaş Odaklı Kamu Hizmeti Yaklaşımı ve Kamu Ekonomisi Bakımından Sonuçları (Türkiye’de Sağlık Sektörü Örneği), Marmara Üniversitesi Sosyal Bilimler Enstitüsü Maliye Ana Bilim Dalı, Doktora Tezi, İstanbul.

Ütük, Utku (2015) “Denhardt ve Denhardt’ın Yeni Kamu Hizmeti Kuramına Bakış”, Sayıştay Dergisi, S. 99, ss. 47-70.

Yegen, Ceren (2013) "Demokratik ve Yeni Bir Kamusal Alan Olarak Sosyal Medya", Muş Alparslan Üniversitesi Sosyal Bilimler Dergisi, C. 1, S. 2, ss. 119-135.

Yükselbaba, Ülker (2008) “Kamusal Alan Modelleri ve Bu Modellerin Bağlamları”, İstanbul Üniversitesi Hukuk Fakültesi Mecmuasi, C. 66, S. 2, ss. 227-271.

Zengin, Ozan (2008) "Kamu Yönetimi Disiplininde Eleştirel Kuram: Box ve Denhardt Üzerine Bir İnceleme”, Amme İdaresi Dergisi, C. 41 S. 3, ss. 1-39. 